\title{
Police Officers' Duty to Rescue or Aid: Are They Only Good Samaritans?
}

Courts often face questions regarding the legal duties of police officers ${ }^{1}$ to individual citizens under tort law, ${ }^{2}$ and the applicability of governmental immunity in cases where a legal duty does exist. The issues are particularly difficult when an officer's alleged negligence involves a failure to act rather than the commission of a harmful act. Because tort law traditionally has been slower to recognize liability for nonfeasance than for actual misfeasance, ${ }^{3}$ both courts and legislatures have typically refused to impose affirmative duties on police officers in the absence of special circumstances. ${ }^{4}$

In Williams v. State, ${ }^{5}$ the California Supreme Court faced these

1. State statutes generally provide that only the governmental entity that employs the officer, rather than the individual public employee, may be held liable for the negligent acts or omissions of its employees, thus insulating the individual police officer from personal liability. See, e.g., infra notes 70-71.

2. The necessary elements for tort liability in a negligence action are: (1) a duty recognized by law; (2) a breach of that duty (failure to conform to the standard of care required); (3) a showing of proximate cause; and (4) actual loss or damage. W. PROSSER, HANDBOOK OF THE LAW OF Torts $\S 30$, at 143 (4th ed. 1971); 4 B. Witkin, Summary of California Law Torts $\S 488$, at 2749 (8th ed. 1974 \& Supp. 1984). Duty is recognized as the "threshold" element in a cause of action for negligence, and hence provides an important limitation in establishing negligence liability. Thompson v. County of Alameda, 27 Cal. 3d 741, 750, 614 P.2d 728, 732, 167 Cal. Rptr. 70, 74 (1980) (noting that courts "have invoked the concept of duty to limit generally "the otherwise potentially infinite liabihty which would follow every negligent act' ") (quoting Dillon v. Legg, 68 Cal. 2d 728, 739, 441 P.2d 912, 919, 69 Cal. Rptr. 72, 79 (1968), in which the court examined the historical context of duty); W. Prosser, supra, $\$ 30$, at 143; see also J. Fleming, THE LaW of TORTs 129-30 (6th ed. 1983).

3. There is a deep-rooted distinction in tort between misfeasance and nonfeasance and the liability resulting from each. Misfeasance is active misconduct causing actual injury to others for which one may be liable. Nonfeasance is a failure to take steps to protect others from harm, i.e. the nonperformance of some act, for which tort law lias been more reluctant to recognize liability. Prosser explains that while "by 'misfeasance' [a] defendant has created a new risk of harm to the plaintiff, . . . by 'nonfeasance' he has at least made his situation no worse, and has merely failed to benefit him by interfering in his affairs." W. PROSSER, supra note $2, \S 56$, at 339 . This distinction, however, is not necessarily a valid one, despite its long tradition. Prosser himself notes the practical difficulties that arise in labeling an event action or inaction, for example, failure to blow a warning whistle. Id. $\S 56$, at 340 . The tenuous nature of the misfeasance/nonfeasance distinction is also discussed infra in text accompanying notes $31-34$.

4. Courts impose an affirmative duty to act only in certain cases: where a "special relationship" between the parties exists, or where one voluntarily goes to the aid of another. In the latter case, one assunnes a duty to perform with reasonable care; this duty may thus require certain acts which the plaintiff relies on the defendant to do. W. Prosser, supra note 2, $\$ 56$, at 344.

5. 34 Cal. 3d 18, 664 P.2d 137, 192 Cal. Rptr. 233 (1983). 
issues and specifically addressed the affirmative duties that the California Highway Patrol owes to the notoring public. This Comment examines the premises underlying the Williams opimion. The Williams court assunied that there is no general duty to aid another, that pohice officers owe only a duty to the public at large, and that the police hence have no legal duty to aid a citizen in distress. As a result, the court applied the Good Saniaritan doctrine ${ }^{6}$ to the officers' actions. However, it is necessary to reconsider these assumptions. The special role played by police in our society, their expertise in and traming for emergency situations, and the on-the-job duties of police during those emergencies all leave the nodern police officer uniquely positioned to effect a rescue. Thus, this Comment suggests that imdividuals engaged in the general practice of police work should owe an affirmative duty to rescue, and that this duty may result in other professional obligations which follow fron the act of rendering aid.

Part I of this Cominent summarizes the facts of Williams and the majority and dissenting opimions. Part II examines the affirmative duties of police as addressed by the najority, Justice Mosk and Chief Justice Bird. Part III exammes the notion of a general duty to rescue, and proposes a police duty to rescue or aid. Part IV discusses the professional standard of care to be applied once the police rescue is undertaken, and how it may encompass further professional duties as well, including such police actions as proper investigation of an accident. To determine what constitutes due care for a reasonable police officer, this standard of care slould be based on the professional practices and operating standards of niodern police forces. Part V addresses the unique problent of governmental liability which arises because police officers are public employees, and balances the proposed police duty to rescue against important policy considerations which underlie statutory governmental immunity. This Comment concludes that recognition of an absolute legal duty of the police to rescue is warranted, and that once undertaken, the rescue and subsequent acts should be judged by a professional standard of care.

I

WILLIAMS V. STATE

\section{A. The Facts}

Plaintiff Della Willianıs was a passenger in a nıving autonıbile

6. The Good Samaritan doctrine, which limits tort liability for a volunteer who aids a stranger in distress, is named from the famous Biblical parable. Luke 10: 30-35 tells of the man beaten by thieves and left by the roadside, whom the priest and Levite pass by, but whom the Samaritan tends to, admmistering aid by treatmg his wounds and bringing him to an inn. 
when a piece of a heated brake drum from a passing truck flew through the windshield of the car and struck her in the face, causing severe injuries and the loss of one eye. ${ }^{7}$ California Highway Patrol officers arrived within minutes of the mishap and investigated the accident. ${ }^{8}$ Plaintiff later brought an action against the state, alleging that the police officers had negligently failed to test the piece of brake drum to determine whether it was still hot and had failed to obtain the identities of witnesses. Moreover, the police had failed to pursue the truck, thus destroying plaintiff's opportunity to obtain compensation for her injuries. The trial court granted the state's motion for judgment on the pleadings, ruling that the state had statutory governmental immunity. ${ }^{9}$ The Cahifornia Supreme Court ruled that the finding of immunity was preinature, but held that the plaintiff nonetheless had failed to state a cause of action because no duty of care was established. The court stated that the highway patrol officers involved were merely acting as Good Samaritans. Furtherniore, no special relationship giving rise to an affirmative duty of the officers to investigate the accident was sufficiently alleged. However, in reversing the lower court judgment, the court directed that the plaintiff be given an opportunity to annend her coinplaimt to furnish additional facts about her encounter with the officers which might state a cause of action.

\section{B. The Opinions}

In an opmion by Justice Kaus, the majority ${ }^{10}$ questioned whether a highway patrol officer who comes to the aid of an injured or stranded inotorist has an affirmative duty to secure inforniation or preserve evidence for civil hitigation between the inotorist and potential tortfeasors. The court reasoned that stopping to aid a inotorist is simply an act of a Good Samaritan offering assistance, and does not, in itself, create a special relationship giving rise to any affirmative duty. ${ }^{11}$

The court initially noted that the issue of statutory immunity should never have been reached by the trial court. Immunity caumot arise until it is established that the defendant owes a duty to the plaintiff and would be liable in the absence of immunity; thus, "[T]he immunity cart [was] placed before the duty horse." 12

7. Williams v. State, 34 Cal. 3d 18, 33, 664 P.2d 137, 146, 192 Cal. Rptr. 233, 242 (Bird, C.J., dissenting).

8. Id. at 27, 664 P.2d at 142, 192 Cal. Rptr. at 238.

9. Id. at 22, 664 P.2d at 138, 192 Cal. Rptr. at 234.

10. Justice Kaus was joined by Justices Richardson, Broussard, Reynoso, and Judge Golde (who was assigned by the Chairperson of the Judicial Council).

11. 34 Cal. 3d at 21, 664 P.2d at 138, 192 Cal. Rptr. at 234.

12. Id. at 22, 664 P.2d at 139, 192 Cal. Rptr. at 235 (relying on Davidson v. City of Westminster, 32 Cal. 3d 197, 649 P.2d 894, 185 Cal. Rptr. 252 (1982)). 
In examining the duty issue, the court first stated that the highway patrol has no express statutory duty to aid motorists under California law. Therefore, the majority used common law tort principles to determine whether the highway patrol officers owed any duty to the plaintiff. Justice Kaus applied the fundamental tort rule that there is no general duty to aid others, but that a Good Samaritan who does so voluntarily assumes a duty to exercise due care in that aid. Specifically, a Good Samaritan may only be found hable "if (a) his failure to exercise such care increases the risk of [the] liarin, or (b) the harm is suffered because of the other's reliance upon the undertaking." 13 The court concluded that a patrol officer who comcs to the aid of an injured or stranded motorist is simply a Good Samaritan and should be held only to that minimal standard of care.

The court also exammed the possibility that there was a special relationship between the motorist and the patrol officers, giving rise to an affirmative duty. The opimion concluded that a requisite factor in findimg a special relationship is detrimental reliance by the plaintiff; mere dependence is insufficient. ${ }^{14}$ Thus, a special relationship allegation must show that the defendant's conduct or promise to provide protection mduced the plaintiff's detrimental reliance on the defendant for protection, giving rise to a duty of the defendant to protect the plaintiff from harm.

Justice Mosk wrote a separate opinion, concurring in the judginent but dissenting from the court's reasoning. ${ }^{15} \mathrm{He}$ took a "moderate position," in which he recognized an implied statutory duty of highway pa-

13. 34 Cal. 3d at 23, 664 P.2d at 139, 192 Cal. Rptr. at 235-36 (citing Restatement (SECOND) OF TORTS $\$ 323$ (1977)).

14. The court examined several appellate cases in reaching this conclusion. See Clemente v. State, 101 Cal. App. 3d 374, 161 Cal. Rptr. 799 (1980) (pedestrian struck by motorcyclist was dependent on highway patrol officer who stopped to investigate; officer liable for failing to seeure motorcyclist's name), rev'd following remand, 147 Cal. App. 3d 49, 194 Cal. Rptr. 821 (1983); Mann v. State, 70 Cal. App. 3d 773, 139 Cal. Rptr. 82 (1977) (highway patrol officer stopped to investigate situation of motorist im stalled car, special relationship created based on dependence between officer and motorist, and officer found liable for failing to place flares belimd car before leaving site); Winkelman v. City of Sunnyvale, 59 Cal. App. 3d 509, 130 Cal. Rptr. 690 (1976) (no special relationship existed between police officers at station and accident victin; police not liable for allowing potential tortfeasor to leave police station without giving identity). In reaching its conclusion, the Williams court disapproved Clemente (which had found a special relationship based only on dependence) to the extent it was inconsistent with its views, 34 Cal. $3 \mathrm{~d}$ at $28 \mathrm{n} .9,664$ P.2d at $143 \mathrm{n} .9,192 \mathrm{Cal}$. Rptr. at $239 \mathrm{n} .9$, and reaffirmed its earhier judgment that Mann (which had also found a special relationship based on dependence) was simply an application of the Good Samaritan doctrine, id. at 26,664 P.2d at 141, 192 Cal. Rptr. at 237. The court also distinguished Mann from Williams, finding that in Mann the officer was liable for failing to protect the plaintiff from future physical harn, as opposed to Williams' allegation that the officer failed to investigate the cause of harm already incurred.

15. 34 Cal. 3d at 28-30, 664 P.2d at 143-44, 192 Cal. Rptr. at 239-40 (Mosk, J., concurring and dissenting). 
trol officers to aid injured inotorists on public highways. However, he concluded that the officers' actions fell under California Government Code section 820.2 , which provides immunity for the discretionary acts of public employees. Thus, Mosk argued that while a duty of care existed, the officers and state were immune from liability under California law.

Chief Justice Bird wrote a lengthy dissent asserting that the majority opinion, in finding no legal duty, "fail[ed] to recognize the expanding nature of the special relationship doctrine."16 She discussed the evolving status of special relationships in tort law and examined two appellate court cases ${ }^{17}$ in which a special relationship between the highway patrol officer and the motorist was found based on inere dependence. She concluded that such a relationship arose between the plaintiff and the patrol officers who assisted her, giving rise to an affirnative duty of the officers. The Chief Justice argued that the plaintiff lad alleged dependency in her complaint because she had been incapacitated, the police had assumed responsibility for the investigation, and it was foreseeable that she would rely on the police imvestigation. Chief Justice Bird also discussed the issue of governmental immunity, and noted that while discretionary governmental acts are protected by governinental immunity statutes, such discretion includes only basic public policy decisions, not subsequent ministerial actions. Because the officers' performance of their investigation was ministerial, no statutory immunuty was available. Hence, the Chief Justice concluded that the plaintiff's complaint stated a valid cause of action. ${ }^{18}$

II

\section{The Affirmative Duty Question: Three Traditional APPROACHES}

The Williams court atteinpted to define the affirnative duties owed by the police to the public. Althougl all three opinions began from the same premise-that the state highway patrol had no duty to go to the aid of motorists-they diverged when analyzing the other sources of a duty of care to the plaintiff. Justice Mosk found a duty in a statutory source, the California Vehicle Code. Justice Bird relied on coinmon law principles and found that a "special relationship" based on dependence between the patrol officer and the mjured motorist created a duty. The majority found no special relationship, and concluded that under the common law doctrine of the Good Saniaritan, the officer

16. Id. at 30, 664 P.2d at 144, 192 Cal. Rptr. at 240-41 (Bird, C.J., dissenting).

17. Clemente v. State, 101 Cal. App. 3d 374, 161 Cal. Rptr. 799 (1980); Mann v. State, 70 Cal. App. 3d 773, 139 Cal. Rptr. 82 (1977).

18. 34 Cal. 3d at 34, 664 P.2d at 147, 192 Cal. Rptr. at 243 (Bird, C.J., dissenting). 
only owed a minimal duty to exercise due care in his rescue performance. This Part argues that none of these opinions resolved the duty issue satisfactorily, and Part III ehallenges the soundness of the rule that the pohice do not have a duty to rescue or aid.

\section{A. The Good Samaritan Approach}

The majority opinion reflects entrenched common law reluctance to inipose affirmative duties. The opinion suffers from three defects. First, it does not address basie differences between a police officer who aids a person while on duty and a private citizen who voluntarily aids another. These differences include the speciahzed traming and expertise unique to police officers, the on-the-job status of patrol officers, and the perceptions that both the publie and the pohice themselves have of the police role. ${ }^{19}$ These factors support botli the recognition of more stringent legal duties for police officers than for ordinary citizens, and the appropriateness of holding officers to a higher standard of care than that expected of a private person. Treating the police as Good Samaritans overlooks these important distinctions between the police and the public.

Second, by categorizing police officers as Good Samaritans, the court also implicitly affirms the notion that police officers may avoid possible tort liability by simply ignormg accident scenes altogether. Although it is unlikely that a police officer would be callous enough to drive by an accident, the possibility that she may freely do so makes hittle sense when slie may be held liable for less consequential acts if she does stop.

Third, the majority in Williams erroneously relied on a similar appellate court case to justify its application of the Good Samaritan rule to California Highway Patrol officers. The majority stated that the Good Samaritan doctrime was applied in Mann v. State. ${ }^{20}$ There, an officer, after investigating a traffic accident, left the scene without leaving warnings for oncoming traffic. However, the appellate court in Mann specifically stated that once the officer had chosen to investigate the pliglit of the stranded motorists, a special relationship based on de-

19. As Justice Mosk noted in his separate opinion, it is "difficult to equate a highway patrol officer who has prescribed duties on public highways with a Good Sanaritan who volunteers to assist a stranger." 34 Cal. 3d at 29, 664 P.2d at 143, 192 Cal. Rptr. at 239 (Mosk, J., concurring and dissenting). It is unlikely that either the motoring public or the patrol officers themselves see their role as that of merely Good Samaritans, since private citizens do not regularly patrol the highways in specially marked cars equipped for emergency situations, while it is the specific job of the highway patrol to do just that.

20. 70 Cal. App. 3d 773, 139 Cal. Rptr. 82 (1977) (personal injury action arising out of a traffic accident in which a traffic officer left two stalled cars and a towtruck on the freeway without taking any protective measures before departing). 
pendence arose between the officer and the inotorist, imposing a limited duty of protection. ${ }^{21}$ While the Good Samaritan rule only imposes liability when the Good Samaritan's charitable acts either increase the risk of harm or cause detrimental reliance, the special relationship doctrine as applied by the court in Mann requires merely a showing of dependence between the motorist bemg assisted and the officer at the scene. $^{22}$ Unlike the Good Samaritan rule, the less stringent dependence standard would allow liability even where the plaintiff could not have detrimentally relied on the officer's presence. Thus, the Williams court improperly relied on this case to reach its conclusion, and the application of the Good Samaritan rule was neither logically persuasive nor justified by precedent. In sum, the Good Samaritan doctrine provides an madequate appraisal of the affirmative duties of police officers to the public.

\section{B. An Implied Affirmative Statutory Duty}

Although he did not find any specific duty of the police to rescue, Justice Mosk argued that a statutory duty to an injured or stranded motorist on the freeway does exist. He examined numerous provisions of the California Vehicle Code and reasoned that although no section explicitly imposed any such duty on the highway patrol, the various provisions together imposed an imphed duty on the highway patrol officer to the injured plaintiff. This conclusion seems intuitively logical. The legislature, however, enacted specific statutes witlim the Vehicle Code setting forth the precise dutics and powers of the highway patrol. $^{23}$ As a matter of statutory interpretation, to disregard the language

21. Id. at 780,139 Cal. Rptr. at 86 .

22. The Cahfornia Legislature subsequently purported to overrule Mann with the enactment of CAL. Gov'T CODE $\$ 820.25$ (West 1980), which reads:

(a) For purposes of Section 820.2 , the decision of a peace officer . . . or a state or local law enforcement official, to render assistance to a motorist who has not been involved in an accideut or to leave the scene after rendering assistance, upon learning of a reasonably apparent emergency requiring his inmediate attention elsewhere or upon instructions from a superior to assume duties elsewhere, shall be deemed an exercise of discretion.

(b) The provision in subdivision (a) shall not apply if the act or omission occurred pursuant to the performance of a mimisterial duty. For purposes of this section, "ministerial duty" is defined as a plain and mandatory duty involving the execution of a set task and to be performed without the exercise of discretion.

This was apparently enacted due to the concern that officers might be found liable for leaving one scene and goiug to another just as urgent. However, the statute's impact is unclear due to the wording of subdivision (b).

23. These specific statutes, found primarily in the California Vehicle Code, typically give the highway patrol the authority to carry out certain functions (i.e. "the highway patrol may do $X$ "), rather than imposing a duty to carry out those functions (i.e. "the highway patrol shall do $X$ "). See, e.g. , CAL. VEH. CODE $\S 2400$ (West 1971 \& Supp. 1984) (highway patrol cominissioner shall have full rcsponsibility and primary jurisdiction for the administration and enforcement of all provisions and laws regulating the operation of vehicles and use of highways); $C_{A L}$. VEH. CODE 
of those statutes is to circumvent the legislature's intent. Under California law, the state highway patrol has the right, but not the duty, either to aid stranded motorists or to investigate accidents. ${ }^{24}$ Thus, although the legislature authorized such affirmative action, it declined to require it, and there is no authority within the Vehicle Code to support Justice Mosk's conclusion.

\section{The Special Relationship Doctrine}

Chief Justice Bird also based her analysis on the presumption that there is no common law duty of the police to rescue, but was more willing than the majority to examine the specific role and capabilities of police officers and to impose a duty because of these factors. Her approach follows a trend in the common law to find exceptions to the general no-duty-to-rescue rule through the special relationship doctrine. ${ }^{25}$ Although the doctrine is not a new one, it has become more

$\S 2401$ (West 1971) (officers are to patrol the highways); CAL. VeH. CODE $\$ 2406$ (West 1971 \& Supp. 1984) (vehicles may be equipped with first aid equipment); $C_{\text {AL. }}$ Ver. CODE $\$ \S 2407-2408$ (West 1971) (highway patrol may conduct research into cause and control of accidents); $C_{A L}$. VEH. CODE $\$ 2410$ (West 1971) (officers may direct traffic); CAL. VEH. CODE $\$ 2412$ (West 1971) (officers may investigate accidents).

24. 34 Cal. 3d at 24, 664 P.2d at 140, 192 Cal. Rptr. at 236 (citing CAL. VeH. Code $\$ 2412$ (West 1971)).

25. The idea that special relations should give rise to liability for nonfeasance originated in cases of "public" callings, and soon extended to other certain recognized rclations in which custom, public sentiment, and social policy have persuaded courts to find an affirmative duty to act. W. Prosser, supra note $2, \S 56$, at 339 . The various categories to which the label "special relationship" applies cover a broad range of relationships, due im part to the fact that policy considerations have played such an important part in the formulation of the doctrine. For example, the term "special relationship" is used where there exists some fanilial, custodial, or personal tie between the two parties as with parent/child relationships, husband/wifc relationships, and a master-of-ship/seaman relationships. See W. LaFave \& A. ScotT, Handbook on Criminal LAw $\S 26$, at 184 (1972). Another category of special relationships is the "quasi-contractual" relationship, includimg that of the innkeeper to his guest, the doctor to his patient, and the lifeguard to his pool's swimmers. Id. at 185; Restatement (SECOND) OF TORTS \& 314A (1965).

Special relationships in modern tort law arise in three additional contexts. First, some special knowledge or responsibility will mvoke a duty to control another person's conduct and/or to protcct an identifiable and foreseeable third party from harm. See, e.g., Hedlund v. Superior Court, 34 Cal. 3d 695, 669 P.2d 41, 194 Cal. Rptr. 805 (1983) (as health care providers, psychologists had duty to warn woman of danger posed by patient); Tarasoff v. Regents of Univ. of Cal., 17 Cal. 3d 425, 551 P.2d 334, 131 Cal. Rptr. 14 (1976) (thcrapist who determined, or pursuant to professional standards should have determined, that a patient posed a serious danger to another was obhigated to use reasonable care to protect intended victim); Johnson v. State, 69 Cal. 2d 782, 447 P.2d 352, 73 Cal. Rptr. 240 (1968) (state held liable for negligent failure to warn foster parents of dangerous tcndencies of ward placed in their home). Second, if a person causes another to justifiably rely on him to the other's detriment, a duty will arise. See, e.g., McCarthy v. Frost, 33 Cal. App. 3d 872, 875-76, 109 Cal. Rptr. 470, 472 (1973) (plamtiffs failed to allege any special relationship based on justifiable reliance by plaintiff on statement or promise); Morgan v. County of Yuba, 230 Cal. App. 2d 938, 944-45, 41 Cal. Rptr. 508, 512 (1964) (special relationship existed when sheriff promised to warn threatened woman of the release of a particular prisoner; sheriff held negligent for failing to give warning). Third, a special relationship may potentially arise 
important in recent years, and has often been relied on in California tort law. ${ }^{26}$ Chief Justice Bird's analysis shows a broad use of the term to encompass any relationship of dependence.

There are two problems with the special relationship approach. First, police officers may avoid the duty and potential liability by declining to stop at accident scenes at all; and second, the doctrine does not define what circumstances constitute sufficient dependence to justify a special relationship finding. ${ }^{27}$ Hence, it does not provide guidance to either courts or the pohice as to when a special relationship arises. As a loosely defined doctrine which may be applied on an ad hoc basis, it should not be mvoked when a more comprehensive approach is available.

\section{III \\ Police and the Duty to Rescue}

This Comment suggests an alternative approach to analyzing the affirmative legal duties of police officers. First, courts and legislatures should recognize a police duty to rescue, by which police and highway patrol officers owe a legal duty to come to the aid of citizens in danger of serious physical harm. Second, once a rescue has begun, the actions of a police officer must be viewed as those of a skilled professional, and a police officer is obligated to exercise that degree of care in carrymg out his duties that a reasonable police officer would exercise under the same circumstances. This approach differs from those presented in Williams in that it recognizes an affirmative police duty to aid a motorist in distress. This duty arises once a police officer learns or should have learned of the motorist's plight. Moreover, the officer must conform to a professional standard in effecting the rescue.

\section{A. The No-Duty-to-Rescue Rule}

American tort law has persistently refused to recognize any general legal duty to come to the aid of another in distress. While the

where there is a relationship of dependency between the parties. Mann v. State, 70 Cal. App. 3d 773, 139 Cal. Rptr. 82 (1977) (highway patrol officer's stopping to imvestigate stranded motorist on freeway resulted in special relationship based on dependence); see also Pamela L. v. Farmer, 112 Cal. App. 3d 206, 169 Cal. Rptr. 282 (1980) (special relationship based on dependence could be inferred between wife of known sex offender and young neighbor girls, who were invited to swim at defendant's house while she was away and husband was alone with girls, thus giving rise to a duty to protect the girls from foreseeable harm); RESTATEMENT (SECOND) OF TORTS $\S 314 \mathrm{~A} \mathrm{com-}$ ment b (1965).

26. See cases cited supra note 25 .

27. In fact, one factor cited by Chief Justice Bird as showing that a relationship of dependence arose was that "it was reasonably foreseeable that plaintiff would rely on [the officer's] expertise . . . 34 Cal. 3d at 33, 664 P.2d at 147, 192 Cal. Rptr. at 243 (emphasis added). This mention of reliance illustrates the confusion that may result in determining dependence. 
concept of this no-duty-to-rescue rule encompasses broader issues than the Williams case addressed, the rule nonetheless underlies the court's general approach. The rule itself has been both adamantly supported and vehemently criticized. This Section will examine the strengths and weaknesses of the rule, laying the foundation for its application to the police in particular.

Courts and commentators have offered numerous justifications for the no-duty-to-rescue rule. The primary justification is based on the lingering reluctance of our legal system to compel action (based on the distinction in tort between inisfeasance and nonfeasance), to enforce moral values too stringently (by compelling action), and to interfere with the individualistic philosophy prevailing in older common law. ${ }^{28}$ The courts have stated that it is improper to force meinbers of society to become Good Sainaritans. As a result,

[g]enerally one has no legal duty to aid another person in peril, even when that aid can be rendered without danger or inconvenience to himself. He need not shout a warning to a blind man headed for a precipice or to an absent-minded one walking into a gunpowder room with a lighted candle in hand. . . . A moral duty to take affirmative action is not enough to impose a legal duty to do so. ${ }^{29}$

Thus, American common law continues to follow the no-duty-to-rescue rule.

Some commentators, however, have adamantly criticized the persistent rejection of a legal duty to rescue ${ }^{30}$ and have presented persua-

28. See Buch v. Amory Mfg. Co., 69 N.H. 257, 44 A. 809 (1897). In Buch, the owner of a mill was found to have no duty to a trespassing eight-year-old child who caught his hand in machinery and was severely mjured. The court's opinion is often cited for the following passage:

Suppose A., standing close by a railroad, sees a two year old babe on the track, and a car approaching. He can easily rescue the child, with entire safety to himself, and the instimets of humanity require him to do so. If he does not, he may, perhaps, justly be styled a ruthless savage and a moral monster; but he is not liable in damages for the child's injury, or indictable under statute for its death.

Id. at 260, $44 \mathrm{~A}$. at 810 . Other famous cases include Handiboe v. McCarthy, $114 \mathrm{Ga}$. App. 541, 151 S.E.2d 905 (1966) (failure of defendant's servant to rescue a four-year-old child who fell into defendant's swimming pool not actionable); Osterlind v. Hill, 263 Mass. 73, 160 N.E. 301 (1928) (defendant rented canoe to intoxicated plaintiff, who upset it and drowned; defendant owed no duty), overruled by Pridgen v. Boston Hous. Auth., 364 Mass. 696, 308 N.E.2d 467 (1974); Yania v. Bigan, $397 \mathrm{~Pa} .316,155$ A.2d 343 (1959) (defendant who urged business invitee to jump into drainage ditch had no duty to rescue him from drowning); see also J. FLEMING, supra note 2, at 138; W. ProssER, supra note $2, \S 56$, at 339 . An interesting collection of essays, providing a general background on the legal duty to rescue in Anglo-American law, is offered in THE GOOD Samaritan AND the Law (J. Ratcliffe ed. 1981). On the moral duty issue, see Ames, Law and Morals, 22 HARV. L. Rev. 97, 103-13 (1908); Bohlen, The Moral Duty to Aid Others as a Basis of Tort Liability, 56 U. PA. L. REv. 217 (1908).

29. W. LAFAVE AND A. SCOTT, supra note $25, \S 26$, at 183.

30. See, e.g., J. FlEMING, supra note 2, at 139 ("Nor is it altogether idle to entcrtain the hope that the demands of elementary civilised conduct will yet be reinforced by legal sanctions, if nothing more onerous than a simple warning would suffice to safeguard a fellow-being from imminent peril to life and limb. . . .); W. Prosser, supra note $2, \S 56$, at 340 (finding court decisions in 
sive counterarguments in support of such a duty. For example, the distmction between misfeasance and nonfeasance, relied on as the underlying basis for the no-duty-to-rescue rule (im support of individualism), is a tenuous one, despite its long tradition in tort law. As noted by one commentator, "The difference . . . is in theory obvious, but in practice it is not always easy to say whether an alleged misconduct is active or passive. There is a borderland in which the act is of a mixed character, partaking of the nature of both."31 A common example of an act of such mixed character is the failure of a tram engmeer to blow a warning whistle: this is technically inaction, but may also be classified as misfeasance, that is, negligent operation of a tram. ${ }^{32}$ Courts' frequent willingness to ignore the line between misfeasance and nonfeasance by finding special circumstances that coinpel some affirmative action demonstrates both the ambiguity and frailty of the distinction. ${ }^{33}$ As a cornerstone for the refusal to recognize a duty to rescue, the distinction lays a weak foundation. ${ }^{34}$

A second argument agamst the no-duty-to-rescue rule is the moral repugnance of not requiring a person to help another in danger. This is a particularly strong argument when the so-called "easy rescue" 35 is involved-where it is obvious how to effect the rescue, and the financial, moral, and personal cost to the rescuer is minimal or nonexistent. For example, someone standimg on a dock may, at no risk and virtually no cost to himself, throw a rope to a drowning person, thereby saving the other's life. It is difficult to conceive of any moral justification for not imposing a legal duty to rescue in such a case. ${ }^{36}$

some of the inore flagrant cases to be "revolting to any moral sense," and citing a compilation of legal writers who have "denounced [such decisions] with vigor," id. § 56, at 341 n.68); M. SHAPO, The Duty to ACT: ToRt LAw, Power AND Public Policy at xii, 64-68 (1977); Ames, supra note 28; Rudolph, The Duty to Act: A Proposed Rule, 44 NEB. L. Rev. 499 (1965); Weinrib, The Case for a Duty to Rescue, 90 Yale L.J. 247 (1980); Woozley, A Duty to Rescue: Some Thoughts on Criminal Liability, 69 VA. L. REV. 1273 (1983); Comment, Beyond Good Samaritans and Moral Monsters: An Individualistic Justification of the General Legal Duty to Rescue, 31 U.C.L.A. L. REv. 252 (1983).

31. Bohlen, supra note 28, at 220 (footnote omitted); see also 2 F. HARPER \& F. JAMES, THE LAW OF TORTS $\$ 18.6$, at 1044 (1956), in which the authors note that "in many situations the distinctions between [acts and omissions] is altogether without significance in the law."

32. Southern Ry. v. Grizzle, 124 Ga. 735, 53 S.E. 244 (1906).

33. Courts have consequently enlarged the number and scope of special relationships for which an affirmative duty may be imposed. See W. ProsSER, supra note 2, § 56, at 338-43; Note, The Duty to Rescue, 47 IND. L.J. 321, 321 \& n.3 (1972); see also supra notes 4, 24.

34. For a dctailed analysis of the limits of nonfeasance justifications, see Weinrib, supra note 30 , at $258-68$.

35. The case for the duty to rescue in "easy rescue" situations is given in Weinrib's article, supra note 30, at 268-93, and in Comment, supra note 30, at 258-63.

36. Courts themselves, dismissing actions under the no-duty-to-rescue rule, have indicated their moral revulsion at the callous inaction of the defendant. See, e.g., Union Pac. Ry. v. Cappier, 66 Kan. 649, 653, 72 P. 281, 282 (1903); Buch v. Amory Mfg. Co., 69 N.H. 257, 260, 44 A. 809, 810 (1897); Yania v. Bigan, 397 Pa. 316, 332, 155 A.2d 343, 346 (1959). 
Fimally, a legal duty to rescue has been imposed in some jurisdictions. More than a dozen European countries have imposed duties on the public to render aid. ${ }^{37}$ These duties have proved a workable incentive toward Good Samaritan behavior. As one scholar notes:

The important fact is that fifteen continental European countries, ten of them sharing our political, social, and economic system, live under such a legal provision, some of them for longer than three score and ten years, and accept it as a matter of course. The duty to rescue seems to have spread recently from country to country. . . . [And no] objections that it would be unworkable were heard . . . 38

Two American states have also enacted duty-to-rescue statutes, ${ }^{39}$ and despite persistent arguments that sucli statutes undermine individualism, no dire consequences have yet resulted. ${ }^{40}$ These laws have proven to be practical responses to the duty-to-rescue problem.

Nonetheless, pragmatic objections to a general duty to rescue do still exist. One practical consideration is the potential problem of multiple tortfeasors, where numerous people are in a position to rescue another in distress, yet none do so. ${ }^{41}$ In such a situation, it is unclear which of the persons should be held liable for faihing to rescue. If only

37. These include Belgium, Czechoslovakia, Denmark, France, Germany, Hungary, Italy, the Netherlands, Norway, Poland, Portugal, Rumania, Russia, Switzerland, and Turkey. Most of these countries impose criminal sanctions for a failure to rescue. See Rudzinski, The Duty' 10 Rescue: A Comparative Analysis, in THE Good SAMARITAN AND THE LAw, supra note 28, at 91; see also Franklin, Vermont Requires Rescue: A Comment, 25 STAN. L. REv. 51, 59 (1972); Note, Duty to Aid the Endangered Act: The Impact and Potential of the Vermont Approach, 7 VT. L. REV. $143,158-60$ (1982).

38. Rudzinski, supra note 37, at 122-23.

39. Vermont and Minnesota are the only states which have enacted any type of duty-torescue statutes. VT. STAT. ANN. tit. $12, \S 519$ (1973) provides:

(a) A person who knows that another is exposed to grave physical harm shall, to the extent that the same can be rendered without danger or peril to himself . . . give reasonable assistance to the exposed person unless that assistance or care is being provided by others.

(b) A person who provides reasonable assistance in compliance with subseetion (a) ... shall not be liable in civil danages unless his acts constitute gross negligence or unless he will receive or expects to receive remuneration. ... . $\$ 100.00$

(c) A person who willfully violates subsection (a) . . . shall be fined not more than

MinN. STat. ANN. $\$ 604.05$ (West Supp. 1984) also makes it an offense to fail to render aid in an einergency, where it can be rendered without danger to the giver or to others.

For a detailed analysis of Vermont's "Duty to Aid the Endangered Act" (\$ 519), see Note, supra note 37 . The author argues that criminal liability alone under the statute may be ineffective in promoting altruism; therefore the act should be liberally construed to impose civil liability as well for failure to rescue, thus encouraging assistance by bystanders as well as compensating injured victims.

40. See, e.g., Note, supra note 37, which assesses the impact of the Vermont statute.

41. The most obvious example of this possibihty is the case of Kitty Genovese, who was stabbed repeatedly in front of her apartment house, while thirty-eight neighbors heard her screams and watched from their windows without calling the police. A. ROSENTHAL, ThIRTYEIGHT WITNESSES (1964). If a duty to rescue existed, the question is whether all of those neighbors should have been held liable for their failure to act. 
one or some of the tortfeasors are identified, it may be unfair to hold those identified wholly liable while others may avoid hability. ${ }^{42}$

Furthermore, by imposing a general duty to rescue on the public, the law may subject potential rescuers to the risk of harm to themselves. One commentator has stated that "[t]]he inost cogent reason for refusing to adopt a rule that one has a duty to aid another in serious peril was the practical consideration of . . . balancing . . . the degree of the victim's peril against the degree of the rescuer's risk." ${ }^{\text {"43 }}$ Courts do not want to expose potential rescuers to unwarranted physical danger.

A final pragmatic concern arises if the rescuer carries out his duty negligently. Courts may find it inappropriate to inflict tort damages (and possible huge economic cost) on a conscientious yet imept rescuer. At the same time, the injured victim should not necessarily be forced to absorb the cost of a bungled and injurious rescue attempt. Each of these considerations is valid. However, each concern may also be satisfactorily met when recognizing a police duty to rescue rather than a general public duty to rescue.

\section{B. A Proposed Police Duty to Rescue}

When applied to police officers specifically, rather than to the general public, the arguments against a legal duty to rescue are unsupportable. Consequently, courts should recognize a pohice duty to rescue. Where a police officer knows, or should know, that a person is in imminent physical danger, and he is able to take affirmative action to assist with no unreasonable risk to himself, ${ }^{44}$ a duty to rescue arises. ${ }^{45}$

\section{Establishing a Legal Duty}

Before presenting the arguments for a police duty to rescue, it is helpful to examme the requisite elements in establishing a legal duty.

42. One proposed solution is to make the several bystanders joint tortfeasors. Weinrib, supra note 30, at 262; Comment, supra note 30, at 271. Another is simply to charge whomever may be identified with a crimmal violation, whether or not the other tortfeasors may be caught or identified. This selective prosecution is analogous to the citmg of a motorist for breaking the speed limit, while many other speeding drivers at the same time escape. Woozley, supra note 30 , at $1290-91$.

43. Scheid, Affirmative Duty to Act in Emergency Situations-The Return of the Good Samaritan, 3 J. Mar. J. PRAC. \& Proc. 1, 4 (1969).

44. See infra note 69 for an explanation of what constitutes an "unreasonable" risk to an officer.

45. Although this Comment suggests that courts should take the initiative in recognizing a police duty to rescue, legislative action imposing the duty by statute may in fact be more appropriate. This is particularly true in California, where the liabilities and immunities of public employees have been very specifically set out by the legislature in the California Tort Claims Act. See infra note 108 and accompanying text. 
California courts have summarized this issue as follows: " ‘J]udicial recognition of [a] duty . . . is initially to be dictated or precluded by considerations of public policy;" "46 thus, "duty' is not sacrosanct in itself, but only an expression of the sum total of these considerations of policy which lead the law to say that the particular plaintiff is entitled to protection."47 Hence, public policy considerations play a vital role in the judicial recognition of legal duties.

A promiment example of the iniportance of pohicy considerations is Tarasoff $\nu$. Regents of University of California ${ }^{48}$ In Tarasoff, the California Suprene Court weighed the pubhic interest in supporting effective treatment of mental illness and in protecting psychiatric patients' privacy rights (as well as safeguarding the confidentiality of psychotherapeutic communication) against the public interest in safety from violent assault. The court concluded that public safety was the niore important consideration. As a result, the court imposed a duty upon psychotherapists to diagnose potential dangerousness in a patient and to exercise reasonable care to protect the foreseeable victinu of that danger. ${ }^{49}$ In recognizing this duty, the court thus demonstrated the crucial role that policy considerations may play in determining a legal duty, particularly where public safety is at issue..$^{50}$

Such policy considerations also play an important role in the argument for a police duty to rescue. In fact, they are particularly relevant in this area because fundainental policy considerations must be balanced: the moral persuasiveness of requiring rescue action versus the concern that individualisn should prevail. Policy considerations relating to a police duty to rescue include the special role of the police in the

46. Smith v. Alameda County Social Servs. Agency, 90 Cal. App. 3d 929, 935, 153 Cal. Rptr. 712, 714-15 (1979) (quoting Peter W. v. San Francisco Unified School Dist., 60 Cal. App. 3d 814, 822, 131 Cal. Rptr. 854, 859 (1976)).

47. Dillon v. Lcgg, 68 Cal. 2d 728, 734, 441 P.2d 912, 916, 69 Cal. Rptr. 72, 76 (1968). See also Thounpson v. County of Alameda, 27 Cal. 3d 741, 750, 614 P.2d 728, 732-33, 167 Cal. Rptr. $70,74-75$ (1980), stating that:

in considering the existence of "duty" in a given case several factors require consideration including . ... the policy of preventing future harn, the extent of the burden to the defendant and consequences to the community of inposing a duty to exercise care with resulting liability for breach, and the availability, cost, and prevalence of insurance for the risk involved. When public agencies are involved, additional elenents include "the extent of [the agency's] powers, the role imposed upon it by law and the linitations imposed upon it by budget."

(citations omitted) (quoting Raynıond v. Paradise Unified School Dist., 218 Cal. App. 2d 1, 8, 31 Cal. Rptr. 847, 852 (1962)).

48. 17 Cal. 3d 425, 551 P.2d 334, 131 Cal. Rptr. 14 (1976).

49. Id. at 440-42, 551 P.2d at 346-47, 131 Cal. Rptr. at 26-27.

50. For another case raising such policy considerations, see Elanı v. College Park Hosp., 132 Cal. App. 3d 332, 346-47, 183 Cal. Rptr. 156, 165 (1982) (holding that a hospital is accountable for negligently screening the coinpetency of its medical staff to insure the adequacy of medical care rendered to patients at its facility, specifically in light of the public health considerations involved). 
protection of public safety, public expectations of police officers in that role, the encouragement of competent and careful police work, and the societal goal of compensating injured tort victims.

\section{The Case for a Police Duty to Rescue}

This Comment argues that a police officer who learns that a citizen is in imminent danger of serious physical larm is under a duty to aid that person. The underlying thesis is based on a coinbination of practical and policy considerations. Most important, the police are specially trained and empowered to protect public safety, and in that unique role should be held to a corresponding legal duty to rescue. Such a duty would also benefit society by proinoting police coinpetence and coinpensating injured tort victims. Further, the imposition of a police duty to rescue is not only inorally justifiable,$^{51}$ but also enforces job-related duties rather than merely moral obligations. Finally, while some practical concerns weigh against a general duty to rescue, those concerns are inapplicable when the duty is only imposed upon the police.

\section{a. The Special Role of the Police}

Pohice officers assume the task of both protecting society at large froln harm and proinoting public safety. As one court has stated,

[P]ublic servants [are] subject not to a mere social obligation, but to what I feel bound to regard as a legal obligation .... The duties which I would lay upon them stem not only from relevant statutes . . . but from [a] . . . conventional or customary duty in the established constabulary as an arm of the State to protect the life, limb and property of the subject. ${ }^{52}$

This special societal role of the police in serving the public is but one factor in the case for a police duty to rescue.

The changing technical coinplexity, custoins, and structure of nodern society have created greater reliance by the public on the police force. Communities have expanded, resulting in larger and better police forces. As a result of decreased community cohesiveness, the availability and appropriateness of informal citizen action has largely disappeared. While citizens a century ago may have been able to rescue a rider thrown from his buggy and chase those responsible for the accident, it is unlikely that the average citizen today would be capable of extricating a motorist froln a severe car wreck or pursuing the reck-

51. Certainly a highway patrol officer who sees a serious traffic accident on the side of the road is morally obliged to go to the aid of that person. As protectors of public safety, the police should also be legally obliged to aid citizens in distress.

52. O'Rourke v. Schacht, [1976] 1 S.C.R. 53, 66 (Canada) (holding police constable contributorily negligent in traffic accident for failing to replace warning signs at excavation site on roadway after previous aceident). 
less driver who caused the accident. Only the police have the expertise and equipment for attempting such rescue and aid.

Police officers undergo extensive training, ${ }^{53}$ including the simulation of rescue efforts, and are much more likely than citizens to have personal experience in dealing with emergencies requiring rescue action. Thus, police today fill the role of professional guardians of the public welfare, ${ }^{54}$ tramed and equipped to protect the public.

A legal duty of the police to rescue comports with public perceptions of the role that police officers play in society. Citizens perceive the police as protectors of the public and guardians of safety. These perceptions in turn give rise to reasonable expectations that the police will come to the aid of a citizen in distress. Thus, citizens typically resort to the police in emergencies. The state-created police force fosters expectations and a general rehance on police services. Since the police force is created by the community to serve its law enforcement needs, these expectations are particularly important in defining the role of the police as public servants, and suggest the appropriateness of a parallel legal duty.

The importance of public expectations and social policies in shaping a legal duty to rescue has been acknowledged by the courts. In Lee v. State, ${ }^{55}$ the Alaska Supreme Court held that police officers do have a duty to rescue, based on the broad duties of the police and public conceptions of the role of police. ${ }^{56}$ The court stated that "a holding that police officers have no duty to rescue would not comport with public conceptions of their role." 57 Thus, the police duty to rescue is in part

53. See H. Earle, Police Recruit Training 63-65 (1973), which states that several broad areas are usually structured into police academy curricula: adininistration of justice, patrol procedures, traffic enforcement (including accident investigation), social science, criminal investigation, emergency medical services, physical training and skills, and agency standards and procedures (citing C. Saunders, Upgrading the American Police 5 (1970)); see also D. Hansen \& T. Culley, The Police Training OfFicer (1973), which offers guidelines as to effective training programs, a top priority for inost police forces.

54. Indeed, were there no organized public police force, private counterparts might emerge (albeit probably on a inuch smaller scale and of lower overall efficiency) and the private protcction or rescue squads would be held by contract to perform this difficult work. However, since the state and municipalities do not allow such private commissioning, and in fact keep police protcction a state/mumicipal monopoly, the public is in turn entitled to rely on ccrtain basic obligations, such as a duty to rescue.

55. 490 P.2d 1206 (Alaska 1971), overruled on other grounds, Munroe v. City Council, 545 P.2d 165, 170 (Alaska 1976). In Lee the plaintiff, a twelve-year-old child, was at an amusement park and stopped to pet a caged lioness. The lioness grabbed the child's arm in its teeth and held her to the bars of the cage. A state trooper then came to the girl's aid, but accidentally shot her in the leg after shooting the animal to free her. The court held that the officcr was under a duty to go to the aid of the child; in hight of that duty he was not protected froin hability under the Good Samaritan statute, and should have been held to a standard of ordinary negligence.

56. Id. at 1209.

57. Id. (emphasis added). The court noted that: 
molded by public expectations.

\section{b. The Benefits of a Police Duty to Rescue}

Recognition of a police duty to rescue would confer two social benefits. First, it would act as an imcentive to police officers to provide better police services. If police departments, municipalities, or the state eould be held liable in tort for their officers' failure to competently rescue, these employers would be under additional pressure to hire capable and careful officers. Thus, officers who perform deficiently would soon be dropped from the force. Under the Williams approach to police liability, a police officer who unreasonably fails to place warning flares around an accident site would not necessarily subject the state or municipality to any liability. Repeated mistakes miglit eventually lead to the officer's dismissal, but in the absence of tort liability, there is a lower incentive to maintain a competent police force. Potential liability provides a powerful incentive toward excellence.

Second, a police duty to rescue would meet the societal goal of compensating injured tort victimis. Because tlie governmental entity (in most cases the state or the municipality) would assume the cost of the breach of the duty to rescue, the victim's loss will be spread among the taxpayers. If a societal goal is the compensation of mjured tort victims, the government may act as an "msurer" agamst police failure to come to the aid of citizens. Taxpayers expect part of their taxes to pay for the cost of an efficient protective police force, and one that will rescue someone in distress. Spreading the loss ensures similar emergency protection for all and compensates the individual who suffers froin a lapse in the quality of that proteetion. Indeed, "[a] large enough governinental unit is the best of all possible loss spreaders . . . ."58 Thus, spreading the loss from a police officer's breaclied duty to rescue by imposing

\footnotetext{
"Whether or not the defendant policeman had any statutory obligation to care for the plaintiff, we think that there was an obligation in fact arising out of the customary role played by police officers in such emergencies, pursuant to their general responsibility of protecting the lives and welfare of citizens at large."

Id. at 1209-10 (quoting Wood v. Morris, 109 Ga. App. 148, 151, 135 S.E.2d 484, 487 (1964)).

58. Davis, Tort Liability of Governmental Units, 40 MiNN. L. REv. 751, 811 (1956); see also Van Alstyne, Governmental Tort Liability: A Decade of Change, 1966 U. ILL. L.F. 919, 921, which states that:

Modern notions of sound public pohicy reject the view that the burden of loss should fall upon the person imjured by the tortious acts or omissions by public servants; on the contrary, it is deemed better, as a rule, to distribute the private losses caused by the governmental enterprise over the public at large which is the beneficiary of that enterprise.
}

Even if the governmental unit is rather small (for example, a small municipality), its loss-spreading capabilities may be enhanced through insurance against governmental tort hability. See infra notes $93-99$ and accompanying text. 
liability upon the public entity is a beneficial and equitable goal for the community.

\section{c. Individualism and the Police Duty to Rescue}

If the legal duty to rescue is recognized as an element of a police officer's job, the traditional arguments that individualisn must prevail and that "the law should not legislate inorality" becone mapplicable. Individualism is not threatened when an affirmative duty to act in a certain manner becones implicit in the enploynent one voluntarily assunies. In that case, the law does not legislate noral duties, but rather employment duties.

Presentimg the duty to rescue as an elenrent of police law enforcement and protection thus meets the argunient of Professor Lon Fuller, who defended the distinction between moral and legal duties. Fuller suggested that certam noral aspirations marking the pinnacle of human achievenent slould be left to the individual himself to judge. In contrast, basic noral duties laying down the absolute rules of an ordered society are left to courts of law to impose as duties. ${ }^{59}$ Thus, acts that aspire toward liuman perfection, that comprise "tlie morality of the Good Life, of excellence, of the fullest realization of human powers," ${ }^{\prime 60}$ are better left witl an individual's inner morality of law than witl courts and constitutions, which "cannot be expected to lay out very nany compulsory steps toward truly significant acconiplishnent." 61 Fuller demonstrates this distinction by analogizing the norality of duty to the rules of grammar, which "prescribe what is requisite to preserve language as an instrunent of communication, just as the rules of a morality of duty prescribe what is necessary for social livmg." 62 In contrast, the morality of aspiration is analogous to the principles of good writimg, which are loose, vague, and indetermmate, and which present "a general idea of the perfection we ought to ainu at, [rather than affording] us any certain and infallible directions of acquiring it." ${ }^{13}$ On Fuller's yardstick, "which begims at the botton1 with the nrost obvious demands of social living and extends upward to the highest reaclies of hunian aspiration," 64 creatimg a duty to rescue in police work does not require that police display extraordmary lieroism or aspire toward liuman perfection, but merely that they perform a requisite function of their occupation. Just as a lifeguard must under law

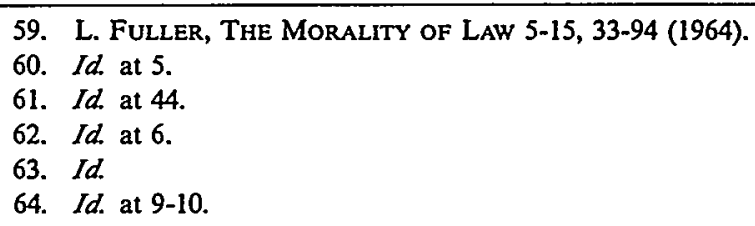


do his best when it is reasonably possible to rescue a drowning person, ${ }^{65}$ so too should a police officer be required to help an imperiled citizen.

\section{d. Practical Considerations: Objections to a Legal Duty to Rescue Do Not Apply to the Police}

Finally, while certain praginatic objections have been raised against a general legal duty to rescue, none apply to a police duty to rescue. The first concern is the problem of inultiple tortfeasors, that is, where a nuinber of people could atteinpt to rescue the victim, but none do. Judicial recognition of a police duty to rescue, however, presents no such problein. The individual police officer notified ${ }^{66}$ of the einergency, or passing by the citizen in distress, is the only potential tortfeasor who might breach the duty to rescue. ${ }^{67}$

A second concern, that the potential rescuer inight be exposed to undue risk in atteinpting a rescue, is also inapposite to the police duty to rescue. From the outset, it is apparent that police officers already assurne a certain degree of risk in their occupation, an admittedly highrisk type of employment. While on duty, police officers routinely anticipate confronting emergency situations. The duty to rescue, along with its assumed risks, can be viewed in part as a duty assumed as an element of the job. ${ }^{68}$ While it might be unfair to expose the general public to the risks involved in rescuing another in distress, the police already

65. See infra note 68 .

66. Such notice might consist of a victim calling for aid, others calling the police on the victim's behalf, the police theinselves discovering a victim's plight, or the police driving by an accident scene or emergency which they should have noticed-one that a reasonably competent police officer would have noticed. The California Tort Claims Act provides certain statutory guidelines on a related issue: public entity liability for creation of a dangerous condition, when the public entity "had actual or constructive notice of the dangerous condition . . . a sufficient time prior to the imjury to have taken measures to protect against the dangerous condition." CAL. Gov'T CODE § 835(b) (West 1980); see also A. VAN ALSTYNe, California Government TORT LIABILITY PRACTICE $\$ \S 3.18-3.22$, at 210-16 (1980). Actual notice requires evidence that the public entity (1) "had actual knowledge of the existence of the condition" and (2) "knew or should lave known of its dangerous character." CAL. Gov'T CODE § 835.2(a) (West 1980). Alternatively, constructive notice exists if "the condition had existed for such a period of time and was of such an obvious nature that the public entity, in the exercise of due care, should have discovered the condition and its dangerous character." CAL. Gov'T CODE $\$ 835.2$ (b) (West 1980). Both definitions inay be used to determine notice in cases of a police duty to rescue as well.

67. In some cases, there may be several officers who are requested to help or who discover an accident. However, it is unlikely that more than several will be imvolved. Any officer identifiably in a position to help slould be under a duty to do so.

68. In this respect, the occupation of police officer is analogous to that of lifeguard. While under traditional tort law an expert swimmer inay callously ignore the man drowning only two feet away, the lifeguard on sliore inay not, and she has a clear duty to go to the drowning person's aid. Kaczinarczyk v. City and County of Honolulu, 65 Haw. 612, 656 P.2d 89 (1982); Sneed v. Lions Club of Murphy, 273 N.C. 98, 159 S.E.2d 770 (1968); S \& C Co. v. Horne, 218 Va. 124, 235 S.E.2d 456 (1977); W. Prosser, supra note 2, § 56, at 340-41; RestatemENT (SECOND) OF TORTS 
anticipate such risks, and are experts in diminishing those risks. ${ }^{69}$

Lastly, the fear of possible huge economic cost to the defendant who fails to rescue, or rescues negligently, is misplaced if the police officer herself would not personally be liable for damages incurred due to a neghigent rescue. Although a well-meaning but inept citizen atteinpting a rescue could be held individually liable if he worsened the victim's phight and caused him injury, police officers as public einployees are typically protected from individual liability for any negligence in their acts or omissions while on the job. California Government Code section 815.2(a) imposes upon public entities vicarious liability for the tortious acts and oinissions of their einployees within the scope of their einployinent, under circuinstances where the employee would be personally liable. ${ }^{70}$ Section 825 requires public entities to pay clains and judgments against public einployees that arise out of their public employinent as well. ${ }^{71}$ Thus, the state or municipality would be liable for dainages in a negligence action against a police officer or highway patrol officer, and the individual officer would not be financially ruined by an "innocent" yet negligent mistake. ${ }^{72}$ In this sense, police officers are ideally suited for a legal duty to rescue, because there would be no cost to the actor, and the duty would be simple to adininister.

The result is a workable, feasible, and reasonable duty to rescue imposed on the police. It is one that requires no undue or extreme behavior on the part of police officers, and coinports with their protec-

\$ 314, comment e (1977); see also J. FLEMING, supra note 2, at 139. The police officer is thus not merely the expert swimmer, but rather the hired lifeguard.

69. Further, a reasonableness standard for the duty itself would also limit any undue risks that a rescue might present. In order for the duty to arise in a specific situation, the officer must have a reasonable means of carrying out the rescue, which would not require him to expose himself to any increased risk or undue harm. In other words, a police officer need not put himself in a life-threatening or dangerous position in order to fulfill the duty to rescue.

70. CAL. Gov'T CODE § 815.2(a) (West 1980) provides that:

A public entity is liable for injury proximately caused by an act or omission of an employee of the public entity within the scope of his employment if the act or omission would, apart from this section, have given rise to a cause of action against that employee or his personal representative.

71. CAL. Gov'T CODE $\S 825$ (West 1980) provides in pertinent part:

If an employee. . . of a public entity request[s] the public entity to defend him against any claim or action against him for an injury arising out of an act or omission occurring within the scope of his employment as an employee of the public entity . . . and the employee . . . reasonably cooperates in good faith in the defense of the claim or action, the public entity shall pay any judgment based thereon or any compromise or settlement of the claim or action to which the public entity has agreed.

...

Nothing in this section authorizes a public entity to pay such part of a claim or judgment as is for punitive or exemplary damages.

72. The subsequent concern of overbroad tort liability for the governmental entity is addressed infra notes $93-99$ and accompanying text. 
tive role in society and with the public's expectations of police responsibility.

\section{IV}

\section{The Professional Negligence Model}

Once a police duty to rescue has been established, courts must apply an appropriate standard of care to that duty. This Part proposes a "professional neghigence model," under which a police officer's actions are tested agamst the standards of a reasonable police officer.

\section{A. The Reasonable Police Officer}

Setting the professional standard of care expected of the "reasonable police officer" should present no undue problems for courts, and will, at the same time, define the scope of the duty to rescue. ${ }^{73}$ Just as mcreasing numbers of professional groups, such as lawyers, doctors, engineers, and architects, are judged by a higher standard of care due to the special skills of their professions, ${ }^{74}$ police officers, too, bring superior knowledge, equipment, training, experience, and skill to their profession of protectmg the public from harm. These professional qualities thus define a professional standard of care for the duty to rescue.

The appropriate standard is that of a reasonable and competent police officer acting in similar circumstances. The specific conduct of a reasonable pohice officer can be deterinmed by exaunining police procedures, departmental rules, training manuals, written guidelines, internal regulations, and other official sources of law enforcement practice, ${ }^{75}$ as well as statutes, ordinances, and expert testimony. All provide clear and explicit guidelines for the proper professional conduct of the reasonable police officer.

73. A professional standards model has been proposed for a police duty to prevent crime. See Note, Police Liability for Negligent Failure to Prevent Crime, 94 HARv. L. Rev. 821, 838-40 (1981). The Note suggests that where police regulations would not govern, expert witnesses could testify as to professional standards and practices. Such an approach would be analogous to that employed by the courts when reviewing medical malpractice or other professional activities. Id.

74. See W. Prosser, supra note 2, at 161-62, noting that professionals in general, including physicians and surgeons, dentists, pharmacists, psychiatrists, attorneys, architects, engineers and accountants, "are required not only to exercise reasonable care in what they do, but also to possess a standard minimum of special knowledge and ability." Id. at 161 (footnote omitted).

75. See A. VAN ALSTYNE, supra note $66, \S 2.71$, at 157 , in which the author comments that "[o]n the issue of due care, manuals of law enforcement practice officially promulgated by the employing entity are generally admissible in evidence if they purport to describe a relevant standard of safe performance of duty." Van Alstyne cites Peterson v. City of Long Beach, 24 Cal. 3d 238, 594 P.2d 477, 155 Cal. Rptr. 360 (1979); Grudt v. City of Los Angeles, 2 Cal. 3d 575, 468 P.2d 825, 86 Cal. Rptr. 465 (1970); Mann v. State, 70 Cal. App. 3d 773, 139 Cal. Rptr. 482 (1977). 
For example, im Peterson v. City of Long Beach, ${ }^{76}$ the California Supreme Court held that provisions of a municipal police department manual governing the discharge of firearms constituted "regulations of a public entity" within the meaning of the California Evidence Code, thus giving rise to a presumption of failure to exercise due care when that regulation was violated. ${ }^{77}$ Thus, municipal police regulations and guidelines can be used to determine the appropriate measure of due care reflected in the police officer's conduct. ${ }^{78}$ This standard avoids potentially capricious jury determmations of police negligence. Rather, it incorporates formal regulations used by police departments themselves to provide procedural guidelines for their officers. Additionally, where precise imternal guidelines of the police or highway patrol do not exist, courts may also turn to statutes, ordmances, departmental rules of different locales, and expert testimony. All provide tangible standards to courts and juries attempting to decide whether an officer behaved "reasonably."

The reasonableness of the regulations themselves will in turn be subject to scrutimy. First, police department attempts to minimize the due care required of their officers by lowermg internal standards can be countercd by judicial imperatives. A profession may not set its own standards of care or conduct. As Judge Learned Hand noted in 1932,

[I]n most cases reasonable prudence is im fact common prudence; but strictly it is never its measure; a whole calling may have unduly lagged in the adoption of new and available devices. It never may set its own tests, however persuasive be its usages. Courts must in the end say what is required; there are precautions so imperative that even their universal disregard will not excuse their omission. ${ }^{79}$

Second, police guidelines are held accountable to general public sentiment and the pressures of the political system. Should the standards be unacceptably low, the pubhic may respond politically. For example, if a local police force adopts rulcs that rcquire only minimal

76. 24 Cal. 3d 238, 594 P.2d 477, 155 Cal. Rptr. 360 (1979).

77. The City of Long Beach Police Department Manual, prescribing certain guidelines for the discharge of firearms by police officers, was taken from a model firearms policy proposed by Professor Samuel G. Chapman, who was assistant director of the President's Commission on Law Enforcement and the Administration of Justice (Task Force on Police). Id. at $242 \mathrm{n} .2,594$ P.2d at 478-79 n.2, 155 Cal. Rptr. at 361-62 n.2.

78. See also Grudt v. City of Los Angeles, 2 Cal. 3d 575, 588, 468 P.2d 825, 831, 86 Cal. Rptr. 465, 471 (1970), presenting a similar factual situation, in which the court stated, “" The safety rules of an employer are . . . admissible as evidence that due care requires the course of conduct prescribed in the rule. Such rules implicitly represent an informed judgment as to the feasibility of certain precautions without undue frustration of the goals of the particular enterprise.' " (quoting Dillenbeck v. City of Los Angeles, 69 Cal. 2d 472, 478, 446 P.2d 129, 132, 72 Cal. Rptr. 321, 324 (1968)).

79. The T.J. Hooper, 60 F.2d 737, 740 (2d Cir. 1932). 
assistance to stranded motorists, citizens in that community may lobby for a change, complain to local politicians, or elect new police officials.

Third, there is already a limited degree of uniformity in many of the existing regulations. ${ }^{80}$ National or statewide norms will also act as a safeguard against lower standards. In sum, there should be no substantial difficulties in the courts' reliance on internal guidelines, manuals, and regulations of police forces as sources of the professional standard of care.

\section{B. The Scope of the Duty to Rescue: Finding Negligence}

The scope of the duty to rescue and the "reasonable police officer" standard can be demonstrated with a few specific examples. For nistance, in Clemente $v$. State, ${ }^{81}$ a pedestrian was hit by a inotorcycle in a crosswalk and seriously injured. A highway patrol officer stopped to investigate, called an ainbulance for the victim, and questioned the inotorcyclist and witnesses. He failed, however, to obtain the cyclist's name, address, or other pertinent information before leaving the accident scene, and the inotorcyclist departed before other police officers or the ambulance arrived. There was therefore no information obtained as to the motorcychist's identity. The injured pedestrian later sued the state for the officer's neghigent investigation.

If there were a police duty to rescue, that duty would have arisen in Clemente when the patrol officer came upon the accident scene. The professional standards model reveals whether the officer fulfilled that duty by simply stopping and attending to the victim's physical injuries, or whether he should have fully investigated the accident as well.

To evaluate the potential liability of a police officer, it is necessary to determine what steps a reasonable, professional police officer would have taken in aiding a motorist at an accident site. According to expert testimony in Clemente, the officer should have followed certani basic steps upon arrival at the scene of the accident: “(1) look to the wellbeing of the victim; (2) get the names of witnesses; (3) secure the safety of the scene; and (4) locate the drivers involved and locate any witnesses."82 Further elaboration of professional standards is provided in the California Highway Patrol Accident Investigation Manual, which supplies clear precise guidelines for investigating a motor vehicle accident. The manual states that in the investigation of an accident,

[a] logical first step [after looking to the well-being of the victim] is to

80. See, e.g., the inodel firearms policy discussed supra in note 77 , which was circulated throughout California. 31832)

81. 147 Cal. App. 3d 49, 194 Cal. Rptr. 821 (1983), hearing granted, Nov. 25, 1983 (L.A.

82. Id. at 53,194 Cal. Rptr. at 823 . 
locate and question the drivers and witnesses. This is done by making a quick preliminary check to see that all drivers are present, then attempting to locate witnesses. The investigator should get the operation license of each driver, determine which vehicle each was driving, and then look for persons who might have seen the accident. ${ }^{83}$

The expert testimony and guidelines demonstrate that highway patrol officers are trained and expected to carry out certain investigative procedures when investigating an accident. These steps comprise a professional standard of care which must be inet to fulfill the required duty. Thus, the officer in Clemente was negligent for failing to investigate the accident pursuant to professional standards.

This extension of the scope of the duty to rescue is not an unreasonable step to take. Under a traditional cost/benefit negligence analysis, ${ }^{84}$ the step is clearly a logical one. Once the officer has taken action on behalf of the victim, the margimal cost of carrying through a competent investigation or rescue is minimal, while the benefit to the victim is enormous. Such conduct comports with internal police guidehines and, additionally, fulfills the expectations of the public. It thus follows easily from the police duty to rescue.

Under this analysis, a police officer may also be held to a professional standard of care where she voluntarily assists a citizen. For example, a police officer might stop to help someone who has not been seriously injured or someone who is in no danger of physical harm. Although no legal duty to rescue arises in either case, the police officer is nonetheless acting in her professional capacity to aid a citizen, with the requisite training and experience to carry out certain expected procedures. Moreover, the officer is still acting within the scope of her job as protector of the public, under the same guidelines for proper conduct. Thus, she must still be held to the standard of care of a reasonable police officer.

Conversely, there will also be occasions in which the police officer's failure to mvestigate or take further steps will not constitute negligence. For example, suppose that in Clemente the plaimtiff and others

83. Id. (quoting the California Highway Patrol Accident Investigation Manual).

84. The weigning of costs versus benefits as a method of determining negligence was unade famous by Judge Learned Hand's classic opinion in United States v. Carroll Towing Co., 159 F.2d 169 (2d Cir. 1947). He proposed what is now known as the "Hand Formula," stating that liability should depend on whether $B<P L$, where $B$ is the burden (cost) of adequate precautions to prevent the accident, $P$ is the probability that harm will occur, and $L$ is the injury (or conversely, the benefit to the victim if the injury is avoided). Id. at 173. Judge Posner saw this as an economic interpretation of neghigence, summarizing that:

[if] the benefits in accident avoidance exceed the costs of prevention, society is better off if those costs are incurred and the accident averted, and so . . . the enterprise is made liable, in the expectation that self-interest will lead it to adopt the precautions im order to avoid a greater cost in tort judgments.

Posner, $A$ Theory of Negligence, 1 J. LeGal Stud. 29, 33 (1972). 
were seriously injured in the accident. An officer would not be negligent in failing to diligently investigate the accident on the plaintiff's behalf if, instead of gathering evidence as the plaintiff requested, he attended to others' injuries first. If witnesses or the driver who caused the accident left the scene while the officer was adininistering first aid, and the officer had failed to obtain those persons' names, the officer would not be negligent. On the contrary, if the officer investigated the accident while severely injured victims needed first aid attention, his inattention to those injured would constitute negligence.

Alternatively, if a person was involved in a minor accident, was not physically injured, and called the police to ask for investigative assistance, the police would be under no legal duty to send an officer to the scene. No duty to rescue arises because there is no serious injury. This result may seein somewhat anoinalous after the Clemente case, but in fact it is not unreasonable or illogical. The immediate need to assist an injured person does not exist and the officer, if not on the scene, has taken no affirmative steps to involve himself in the situation. Moreover, if the police inust send an officer to investigate such a minor accident, the cost of investigation is high, while the benefits are minimal.

The scope of the police duty to rescue extends beyond traffic accidents. In Warren $v$. District of Columbia, ${ }^{85}$ the plaintiffs were awakened one night by the sounds of intruders. One of the plaintiffs telephoned the police and was assured police assistance would be dispatched promptly. After seeing one police car drive through the alley behind their house without stopping, the plaintiffs called the police a second time, but this call was not relayed by the dispatcher. Thinking that the police had entered the house, the plaintiffs called downstairs, and alerted the intruders to their presence. They were then abducted and held captive for the next fourteen hours. They subsequently filed suit against the city for negligent failure to provide adequate police services.

In this case, a duty to rescue arose when the plaintiffs initially made their urgent phone call to the police requesting help. Althougl the police responded promptly to that plea for assistance, the duty was breached when the police officers negligently followed tlirough on that call. The police failed to take any serious measures in response to the call, and thus failed to adequately respond to an emergency situation. As a result, the plaintiffs were injured and should be compensated. ${ }^{86}$

Again, however, the facts in Warren may be altered slightly to

85. 444 A.2d 1 (D.C. 1981 ).

86. The Warren court, however, held that absent a special relationship between the police and an individual, no specific legal duty arises requiring the police to provide police protection. The majority opinion in Warren found no such special relationship and held for the defendant. 
demonstrate reasonable care on the part of the police. If, for example, the police hurried to the scene but arrived after the plaintiffs had been abducted, or made repeated attempts to locate the plaintiffs and enter the house but were unsuccessful, their actions would have sufficiently fulfilled their duty to rescue. The reasonable police officer standard would, after all, only require reasonable behavior, even if set by professional guidelines. Warren represents a particularly hard case because it demonstrates the difficulty of drawing the line between a police duty to rescue and a police duty to protect the public from crime. However, the case deinonstrates that a police duty to rescue may arise when crimmal activity threatens imminent physical danger to a person and a police officer can reasonably effect a rescue.

\section{$\mathrm{V}$ \\ GOVERNMENTAL IMMUNITY}

Once the police duty to rescue is defined, it is necessary to place the governmental "immunity cart" behind the "duty lorse." In fact, the duties and immunities of governmental entities are closely intertwined, and it is difficult to separate them into two neat and distinct categories. In a comprehensive framework, the two work together; courts inay or may not impose a legal duty upon a governinental officer depending on whether the court believes that immunity for the officer's act or omission should be conferred. The two questions raise similar, if not identical, policy considerations of the proper role of tort law in controlling governmental actions. This is particularly so in the fine balancing that must be done when bestowing unique powers upon an entity and then assessing potential liability for the consequences of executing those powers.

Nonetheless, courts tend to separate the two issues tidily into the "duty horse" and "immunity cart." Because police officers are public einployees, statutory governmental immunity inay be applied to their negligent acts or omissions as a basis for limiting governmental tort liability. Existing statutes, however, do not exphcitly address whether immumty could be invoked for duty-to-rescue cases. ${ }^{87}$ Hence, it is unclear whether these statutes should be interpreted as providing governmental immunity for a breach of the proposed police duty to rescue.

87. The California Tort Claims Act, discussed infra in text accompanying notes 108-12, provides statutory immunity for public entities and employees. Sections that pertain to police activity are CAL. Gov'T CODE $\$ \S 818.2$ \& 821 (West 1980) (immunity for failure to enforce the law); $k d$. $\$ 820.4$ (immumity for acts and omissions in the course of enforcing the law while exercising due care); $i d$. $\$ 845$ (immunity for failure to establish a police department, failure to provide police protection service, and failure to provide sufficent police protection service when provided); and most importantly, $i d$. $\$ 820.2$ (immunit, for acts and omissions that result from the exercise of discretion). 


\section{A. Governmental Immunity and the Police Duty to Rescue}

Statutory governmental immunity plays a definitive role in limiting the tort liability of public entities. There are a number of arguments advanced in support of governmental immunity, and eaclı nust be examined specifically with regard to the police duty to rescue.

The first argument in favor of governmental immunity is the fear that, without immunity, the already overworked court system will be flooded with vast numbers of tort suits, ${ }^{88}$ thus congesting the courts and the judicial system. However, this fear has often been criticized, principally because it has proved to be groundless in otler areas where tort liability has been expanded. ${ }^{89}$ Since the recognition of liability under the police duty to rescue would only allow liability in one specific area of public entity torts, any litigation increases would be limited to that area.

Extensive litigation might also lead to large damage awards imposing a huge burden on governmental treasuries to the detriment of the general welfare. This fiscal risk is substantially lower for a large entity such as a state government, which has nore extensive resources than a smaller unit such as municipality. ${ }^{90}$ Nevertheless, cataclysmic damage awards reinam a legitimate concern to any governmental entity, due to insolvency fears, potential drams on the governmental treasury, and revenue-raismg problems. ${ }^{91}$ This is especially so because governmental entities take on such wide-ranging responsibilities and services that the scope of their activities may expose them to broad tort liability far in excess of the risks normally encountered in the private sector. The specter of huge awards is maximized where the activities "carried on by the government are of a nature so inherently dangerous that no private enterprise would wish to undertake the risk of administering them," ${ }^{22}$ as, for example, law enforcement, firefigliting, and

88. This has been labeled the "floodgates of litigation" argument. Note, Municipal Tort Liability for Failure to Provide Adequate Police Protection in New York State, 39 ALB. L. REv. 599, 602 (1975).

89. See, e.g., Samore, Codhing v. Paglia: Comparative Negligence, 38 ALB. L. REv. 18, 19 (1973) (describing these arguments as "the hoariest, as well as the most common, arguments against changes in the law"); Comment, Torts-Illegitimate Child Denied Recovery Against Father for "Wrongful Life", 49 IowA L. REv. 1005, 1014 (1964). An illustration of the unfounded fear of a flood of lawsuits is given in Roberson v. Rochester Folding Box Co., 171 N.Y. 538, 64 N.E. 442 (1902), in which the court feared that the floodgates of litigation would be opened by recognizing a right to privacy. However, jurisdictions which have recognized the right to privacy have found that fear to be groundless. See Comment, supra, at 1014.

90. See Van Alstyne, supra note 58, at $971 \mathrm{n} .365$.

91. Perhaps the best example of this problem arose in the prominent case of Dalehite $v$. United States, 346 U.S. 15 (1953), in which a ship loaded with highly flammable fertilizer exploded in a Texas harbor, killing more than 560 people, injuring 3,000, and causing millions of dollars worth of property damage. The claims against the U.S. government totaled $\$ 200,000,000$.

92. Kennedy \& Lynch, Some Problems of a Sovereign Without Immunity, 36 S. CAL. L. REV. 
maintenance of inental hospitals and penal institutions. Hence, budget considerations are valid policy considerations in the examination of the duty to rescue.

There is no simple solution to these financial concerns. Although one commentator stated in 1966, "[t] $]$ he fear that large unanticipated impositions upon public funds will be required to satisfy tort damage claims is exaggerated," $" 93$ this fear has become more legitimate in recent years. In the 1960's, even if significant tort dainages were likely, those dannages could be met largely through private insurance coverage against government tort liability. "[T] he ready availability of liability insurance provide[d] adequate protection at noderate cost which [could] be budgeted in advance." 94 Typically, legislatures authorized the use of public funds to provide full coverage for the protection of both public entities and public einployees, ${ }^{95}$ and the use of insurance was a practical means for public entities to guard against large tort dainage awards. In the 1970's, however, the ready availability of insurance at an affordable cost deteriorated drastically for California ununicipalities, ${ }^{96}$ and insurance has consequently becone a less reasonable

161, 177 (1963). This article was written at the time the Cahfornia Legislature was preparing to enact the Cahfornia Tort Claims Act, and summarizes the various dangers and fears of opening the government up to tort hability.

93. Van Alstyne, supra note 58, at 921; see also Stone \& Rinker, Governmental Liability for Negligent Inspections, 57 TuL. L. REv. 328, 341-42 (1982) ("The myth that numerous tort suits against the state or municipality will arise and bankrupt or seriously impair the functioning of those entities has been greatly exaggerated."). Stone and Rinker also argue that since there is no logical relationship between a government's finances and proof of negligence, ability to pay should be irrelevant; that governmental units have regularly paid tort judgments without experiencing crippling financial crises; and that such arguments were made when strict hability was imposed on manufacturers and sovereign immunity was abandoned, but were proved unfounded.

94. Van Alstyne, supra note 58, at 921.

95. Id. at 977; see also Davis, supra note 58, at 763 , who notes that "[l]egislators who are wary of making state or local units liable for torts are imcreasingly willing to provide for payment of premiums for liability insurance." See generally David, Tort Liability of Local Govermment: Alternatives to Immunity from Liability or Suit, 6 U.C.L.A. L. REv. 1, 45-53 (1959); Gibbons, Liability Insurance and the Tort Immunity of State and Local Government, 1959 DUKE L.J. 588.

96. This is best demonstrated by the crisis period of 1974-76, in which insurance premiums increased dramatically and many imsurance companies canceled governmental entity policies, most notably Chubb/Pacific Indemnity, which at the time was the largest insurer of public entities in California, representing $65-70 \%$ of the municipal liability business. California CitizEnS Commission on TORT Reform, Staff Background PAPER on Government Liability 82-89 (1977) [hereinafter cited as Citizens Commission]. In June 1976, the situation was summarized as follows:

The days of counties being able to buy first dollar insurance coverage at low cost are gone. Fewer insurance companies are willing to insure public entities, particularly counties and cities. The compames that have remained as potential markets are demanding higher premiums, higher deductibles, and more restrictive coverage. As a result, counties are finding it financially advisable to implement programs of risk reduction, selfinsurance and selective insurance purchasing.

Id. at 87; see also Institute for Local Self Government, Public Agency Liability 36-37, 43-45 (1978) [heremafter cited as INSTITUTE]. 
solution to the budgetary problems. Risk management ${ }^{97}$ and self-insurance ${ }^{98}$ have been increasingly recognized as potential avenues for dealing with public tort hability, and may help solve the problem of the decreased availability of private msurance.

An alternative (and solnetimes concurrent) method of protecting the government treasury from rumous damages is a statutory ceiling on the damages awarded agamst public entities. Sucl a ceiling restricts, but does not totally forestall, tort hability. These limits have been adopted by a number of states for actions against governmental units as a reasonable method of protecting the entity's finances. ${ }^{99}$

A second major fear in recognizing a police duty to rescue is that public services and police programs might be discouraged in the face of potential hability for inaction. For example, the Cahfornia Highway Patrol might send out fewer patrol cars in order to limit the nuniber of

97. Risk management involves preventative measures aimed at the control of risks of accidental loss. The objective is to recognize and control risks, and to protect the entity against catastrophic financial losses at the lowest possible long-term cost, while also preventing losses and injury to public property, public einployees and private citizens. Cirizens Commission, supra note 96, at 110; INSTITUTE, supra note 96, at 55.

98. Self-insnrance is a method used by public entities to pay all or part of their losses theinselves, rather than to purchase full coverage from a commercial insurer. INSTITUTE, supra note 96 , at 95. Many entities, mcluding the State of California, have become self-insurers. For the state, the California Legislature allocates a certain amonnt (\$2 million in 1977) to the Office of the Attorney General to handle general hability claims. Citizens Commission, supra note 96, at 115 .

99. The typical pattern for snch damage ceilings is a specific statutory limitation upon the amonnt of tort damages which may be recovered by any single claimant, with a higher statutory limitation upon aggregate dainages for a simgle occnrrence. See, e.g., FLA. STAT. ANN. § 768.28(5) (West Supp. 1984) (\$100,000/claimant, $\$ 200,000 /$ occurrence; inore by act of legislature); MiNN. STAT. ANN. \$ 3.736 subd. 4 \& 4a (West 1977 \& Supp. 1984) (\$100,00/claimant, $\$ 500,000 /$ occurrence until August 1984 , then $\$ 200,000 /$ claimant, $\$ 600,000 /$ oceurrence, except for securities torts: $\$ 100,000 /$ claimant, $\$ 500,000 /$ occurrence); MONT. CODE ANN. \$2-9-107 (1984) (\$300,000/clainant, $\$ 1,000,000$ /oceurrence; statute terminates $6 / 30 / 85$ ); OR. REV. STAT. ANN. $\$ 30.270$ (1983) $(\$ 50,000 /$ claimant for property damage; $\$ 100,000 /$ claimant, $\$ 300,000 /$ occurrence for all other claims); UTAH CODE ANN. \$ 63-30-34 (1953 \& Supp. 1983) (\$250,000/claimant, \$500,000/occurrence, $\$ 100,000$ for property dainage); WIS. STAT. ANN. $\$ 893.80(3), .82(4)$ (West 1983) (\$50,000/ claimant, $\$ 25,000$ if volunteer fire company sued, $\$ 250,000$ if state einployee sued).

There are objections to this approach. The inost significant is that "instances will arise in which the maximum damages allowable will bear no rational relationship to the actual damages sustaimed, and eqnally deserving claimants will receive grossly disproportionate awards," thus creating disparate resnlts. Van Alstyne, supra note 58, at 971. Professor Van Alstyne also points out that these "necessarily discriminatory consequences" suggest possible constitutional difficulties. However, a set damage amonnt (such as a fixed ceiling of $\$ 50,000$ ) is not the only statutory alternative for limiting damage awards. For exanple, the legislatnre could authorize a ceiling of actual medical expenses or actual property dainage (or a percentage thereof, up to a certain fixed ceiling). Similarly, a certain percentage of medical expenses and property damage plus a set dollar amount could be awarded, in order to compensate actual expenditures in addition to intangible costs of injury such as enotional suffering. This alternative would probably be nost equitable for individnal plaintiffs and would not impose too great a burden on governmental entities. Enactimg a statntory damages limit for the negligent acts or omissions of governmental bodies is a possible compromise between societal and governmental interests, and might be suitable for actions alleging a breach of the duty to rescne. 
on-duty officers, lest they be sued for breach of their duty to aid once they are on the job. However, a pohicy decision of this type is still subject to the local pohtical process, public review, and pubhic opinion. A number of legal commentators liave strongly attacked the notion that public programs would be discouraged by increased tort hability, arguing instead that potential liability is just as likely to have a salutary effect on governmental activity. ${ }^{100}$ Potential hability may certainly act as an incentive to provide more careful and competent service.

In addition, judicial review of governmental acts nay be inappropriate under the "separation of powers" doctrine. Judges may be reluctant to interfere with governmental decisions, particularly in the executive or legislative area. And in the upper-level echelons of government, "[m]uch of what is done by officers and einployees of the government must remain beyond the range of judicial inquiry, as it always has been." 101

However, the fear of unwarranted judicial interference is mitigated by the immunity afforded "discretionary" acts of public employees under the California Tort Claims Act. ${ }^{102}$ High-level policy decisions are not subject to judicial review because government officials are provided statutory immunity. For exaunple, a pohice chief's decision to implement a crime-prevention prograin would be immune from attack through a tort action. In contrast, lower-level ministerial decisions of eunployees are appropriately subject to judicial review under common law tort standards which the courts are competent to apply.

100. See, e.g., M. ARonson \& H. Whitmore, PUblic Torts And Contracts 107-08 (1982); Davis, supra note 58, at 755; James, Tort Liability of Governmental Units and Their Officers, $22 \mathrm{U}$. CHI. L. Rev. 610, 652 (1955); Stone \& Rinker, supra note 93, at 343-44; see also Note, supra note 73, at 833-34.

101. Davis, supra note 58, at 794.

102. The most significant governmental immunity provided for in the California Tort Claims Act is that of discretionary immunity. Under Government Code $\$ 820.2$ the discretionary acts of public employees are immune from potential tort liability. Section 820.2 states in pertinent part that "a public employee is not liable for an mjury resulting from lis act or onnission where the act or omission was the result of the exercise of the discretion vested in hin, whether or not such discretion be abused.' CAL. Gov'T CODE $\S 820.2$ (West 1980).

A principal problem in applying the discretionary immunity doctrine has been formulating a clear and workable definition of what is meant by "discretion." If "discretion" is interpreted literally, it would result in full immunity for all governmental decisions at every level since inost acts of public einployees involve some degree of discretiou. However, in 1968 the California Supreme Court rejected a senuantie or literal approach in defining the term "discretionary." Johnson v. State, 69 Cal. 2d 782, 447 P.2d 352, 73 Cal. Rptr. 240 (1968) (state owed duty to warn foster parents of teenage parolee's homicidal tendencies; failure to warn was not a discretionary decision). Instead, the court articulated a new standard, limiting the application of diseretionary immunity to basic policy decisions entrusted to coordinate branches of government. Subsequent actions in the implementation of that basic policy decision are mimisterial, not protected by governmental immunity, and inust face case-by-case adjudication on the question of negligence. Id. at 797, 447 P.2d at 362, 73 Cal. Rptr. at 250 . Thus, discretionary immunity of public entities applies only to policy-level decisions of public employees. 
Hence, assuming a duty to rescue exists, a police officer's decision not to answer a plea for help or police assistance, or his acts in responding to the duty to rescue, would be subject to the professional negligence standard of due care. ${ }^{103}$ Thus, the existing statutory law already provides for the separation of powers and judicial review concerns in the duty to rescue context.

None of the traditional arguinents supporting an immunity defense are sufficient to negate the duty to rescue rule. The major objection, that such a duty would expose governmental entities to unlimited tort liability, is a valid concern; lowever, it is a concern that is not unique to this particular duty. The fear of tort daniages does not undermine the reasonableness of imposing a duty on police officers to rescue. Moreover, this fiscal problen may be alleviated by insurance, ${ }^{104}$ by initiating risk-manageinent programs, ${ }^{105}$ by self-insurance, ${ }^{106}$ or by setting a legislative ceiling on damages. ${ }^{107}$ Traditional argunients underlying governmental immunity are misplaced in viewing the duty to rescue.

\section{B. California Governmental Immunity Statutes}

The California Tort Claims Act, ${ }^{108}$ enacted in 1963, superseded common law rules on sovereign immunity and set fortl in statutory form the basic rules governing the liabilities and immunities of California public entities and enıployees. Three general principles underlie the Tort Clainis Act: ${ }^{109}$ (1) all tort liability of public entities is constitutional or statutory in origin, ${ }^{110}(2)$ statutory liabilities are subject to and superseded by statutory immunities, ${ }^{111}$ and (3) public einployees are hable to the same extent as private persons for acts and omissions in the scope of their public employinent, except where they are given immunity by statute. ${ }^{112}$ The explicit statutory provisions of the Tort

103. This does not mean, however, that there is automatic liability. A plaintiff inust still show that the duty was breached, and that the police officer did not use reasonable care in his actions. If, for exaunple, another emergency exists, a police officer might not be negligent in leaving the scene. See supra pp. 684-86.

104. See supra text accompanying notes $94-95$.

105. See supra note 97.

106. See supra note 98.

107. See supra note 99 and accompanying text.

108. The Tort Claims Act was enacted in six separate legislative measures. The first of the six measures covers the substantive liabilities and immumities of public entities and employees, and is contained in CAL. Gov'T CODE $\$ \S 810-895.8$ (West 1980 \& Supp. 1984).

109. See A. VAN AlstYNe, supra note 66, § 2.52, at 112.

110. Id. (citing CAL. Gov'T CODE $\S 815$ (West 1980)).

111. Id. (citing CAL. Gov'T CoDE $\$ 815$ (West 1980) (legislative committee comment)); see also id. $\$ 2.26$, at 67 .

112. Id. (citing CAL. Gov'T CODE $\$ 820$ (West 1980)). 
Claims Act wholly govern the tort hability and immunity of public entities in California.

The police duty to rescue may be analyzed under the California immunity statutes that specifically apply to police activity. The most significant immunity statute that may be applied to police beliavior is California Government Code section 820.2, which provides complete immunity for "discretionary" decisions of governmental officials. Discretionary immunity ${ }^{113}$ is an important means of protecting basic policy determinations and high-level discretionary decisions of public officials. ${ }^{114}$ Yet it clearly should not apply to the police duty to rescue, which would involve only "ministerial" actions of officers on duty. An example of this discretionary/ministerial (and hence immunity/liability) dichotomy relevant to the duty to rescue is the growimg implementation of emergency " 911 " services. Under discretionary immunity, a police department may not be sued for failing to provide an emergency "911" service to the public, since this imvolves a major policy decision of police or city officials. However, as the New York Court of Appeals recently ruled, where such a service is provided, and the police assure a victim who calls the " 911 " number that help will be there "right away," the municipality is required to exercise ordmary care in the performance of the duty it has voluntarily assumed. ${ }^{15}$ Thus, all discretionary decisions regarding departmental plannimg, the allocation of rcsourccs, the allotment of time and money to certam services, and other policy

113. See supra note 102 for additional discussion of discretionary immunity.

114. The discretionary exception is also the most important exception under the Federal Tort Claims Act, 28 U.S.C. \$ 2680(a) (1976), preceding and similar in concept to the California Tort Claims Act. The United States Supreme Court first authoritatively interpretcd the discretionary exception in Dalehite v. United States, 346 U.S. 15 (1953) (suit agaimst government for damages caused by an explosion of a ship in a harbor), in which the Court found no government liability by holding that "[t]he decisions held culpable were all responsibly made at a plannimg rather than operational level." Id at 42 . This standard was affirmed in Indian Towing Co. v. United States, 350 U.S. 61 (1955), where the Court stated that "[t]he question [was] one of liability for negligence at what this Court has characterized the 'operational level' of governmental activity." Id. at 64. The Court thus drew a line for federal tort cases between high-level, planning and policy decisions (immune under the discretionary exception) and lower-level, operational decisions (not immune, even if those decisions involve some degree of discretion im the literal sense).

The discretionary/ministerial distinction for public entity iminunity is valid, and should continue to be recognized and followed under any governmental liability analysis. The test is particularly important im the realm of executive or legislative decisions, where judges and juries may not be competent to second-guess unajor policy decisions. See Davis, supra note 58, at 804-08. In effect, it is a recognition of two ideas: (1) that some decisions entrusted to the legislative and executive branches of government should be beyond judicial review; and (2) that governmental units sometines should be immune from liabihty, even when their agents may be at fault. Although a discretionary determination will still have to be decided by the courts on a case-by-case basis, it is an important test that should be imcorporated imto any further analysis of governmental liability. For a discussion supporting the need for immunity for some discretionary functions, see Davis, supra note 58, at 798-800. For an opposing viewpoint, see James, supra note 100, at 651-52.

115. DeLong v. County of Erie, 60 N.Y.2d 860, 457 N.E.2d 717, 469 N.Y.S.2d 611 (1983). 
decisions reinain immune froin tort liability. Only ministerial acts of police officers, including negligent acts or omissions under the duty to rescue, are subject to judicial review. The recognition of a police duty to rescue would not diminisls the scope of discretionary immunity.

Other statutes granting governmental immunity apply expressly to police activity. For instance, California grants immunity for a governmental official's (including a police officer's) failure to enforce the law. ${ }^{116}$ This immunity is provided because it would be an excessive burden on the police to require enforceinent of every law, and it would be impractical to hold the police accountable for all injuries resulting from that nonenforceinent. Nonetheless, in the actual execution or enforcement of the law, a public einployee is only immune for injuries inflicted by his acts or omissions if he was exercising due care. ${ }^{17}$ Similarly, the duty to rescue does not require that police be available to come to the aid of every person in distress. However, when they do provide aid, the police inust do so in a professional inanner. The immunity statutes recognize that there are certain occasions in which governmental hability is appropriate.

Cahfornia also provides immunity to public entities and public employees for failure to provide sufficient police protection service. ${ }^{118}$ Decisions by public officials on the level of police protection are discretionary policy decisions which should not be litigated in tort suits. ${ }^{19}$ In the same manner, however, "immunity is not applicable to ordinary police neghigence in carrying out investigative, protective or traffic safety responsibilities, as distinguished from a failure to provide police service." 120 Similarly, the duty to rescue would involve only ordinary police negligence and not a policy-level discretionary decision.

In sum, existing statutes do not require the invocation of statutory immunity for the duty to rescue. The statutes are not adversely affected, nor is the immunity provided under them nullified; by a recognition of the duty. Whether acknowledged by the courts. or by the California Legislature, the police duty to rescue should be recognized as a reasonable legal duty of police officers to which governmental imnunity does not apply. ${ }^{121}$

116. CAL. Gov't CODE $\S 818.2$ (West 1980).

117. CAL. Gov'T CODE $\S 820.4$ (West 1980).

118. CAL. GOV'T CODE $\S 845$ (West 1980).

119. A. VAN ALSTYNE, supra note $66, \S 4.21$, at 361 .

120. Id. $\$ 4.21$, at 362 (emphasis added) (citing McCorkle v. City of Los Angetes, 70 Cal. $2 \mathrm{~d}$ 252, 449 P.2d 453, 74 Cal. Rptr. 389 (1969)); Mann v. State, 70 Cal. App. 3d 773, 139 Cal. Rptr. 82 (1977).

121. If a police duty to rescue were to be recognized by either the courts or the legislature, any enactment of governmental immunity would obviously be self-defeating. 


\section{CONCLUSION}

The police duty to rescue (with its professional negligence standard) is proposed as an alternative to the existing Good Samaritan rule and the special relationship doctrine. Both existing standards impose limited affirnative duties to act, but madequately address the role of police in society. The inajority approach in Williams unsatisfactorily labeled police officers as Good Samaritans. This traditional approach should not be applied to police officers because it ignores the special expertise of the police in rescue situations, and assumes that the police may ignore citizens in distress. Chief Justice Bird's dissent, while recognizing a broader duty through a special relationship, was also insufficient in its scope. ${ }^{122}$ Even liberal application of the special relationship doctrine does not adequately respond to public expectations and the duties required of the police.

The proposed duty to rescue creates, in effect, a special relationship between all police officers and every nember of the public. In a general sense, the unique role of the police in society places them in a continuous special relationship with the public. ${ }^{123}$ This relationship induces special dependence and reliance upon police to enforce the laws and protect citizens from harn, giving rise to an affirnative duty of protection.

However, the duty to rescue differs fron the special relationship doctrine in three distinct ways. Most important, the special relationship doctrine as defined by eitler the Chief Justice or the majority opinion does not give rise to any initial duty to rescue-the affirmative duty arises only after the officer lhas in some way involved himself.

122. In Williams, the State of California specifically asked the court to wholly "reject the special relationship doctrine as a vehicle for imposing liability against law enforcement agencies and their officers." Answer/Brief in Opposition to Petition for Hearing Granted by the California Supreme Court for Appellee at S, Williams v. State, 34 Cal. 3d 18, 664 P.2d 137, 192 Cal. Rptr. 233 (1983) (on file with the California Law Review). The state noted that:

This case represents an opportunity to immunize the police function from tort liability from the inception of its exercise to the point of arrest, regardless of whether the alleged wrong be labelled "discretionary" or "ministerial," and irrespective of whether a special relationship can be alleged to have existed between the injured party and the peace officer charged with having negligently performed a police function.

$I d$. at 8 . The court declined to imvoke such broad immunity for police actions, but rather enunciated the requisite element of detriunental reliance.

123. Chief Justice Bird's expansive interpretation of the special relationship doctrine is in fact very similar to the proposed pohice duty to rescue. The Chief Justice argued that a showing of one party's dependence upon another may alone be sufficient to establish a special relationship giving rise to an affirmative duty to assist or protect the injured party. However, this argument, although requiring inerely a showing of dependence, applies only to a relationship between an individual officer who has voluntarily gone to a rescue and the citizen being rescued. It does not apply to the police force in general or the public at large. 
Thus, the doctrine would not require a police officer to stop initially and aid a person in distress.

Second, the special relationship doctrine requires a showing of dependence, while the duty to rescue does not. ${ }^{124}$ Although dependence may be a strong underpinning of the duty to rescue, the duty arises not because of an isolated event which creates dependence. Rather, the duty arises because the existence of a professional police force vested with certain powers over citizens results in a general dependence of the public on the police officer for aid. Thus, the duty requires neither specific action nor specific factors giving rise to dependence.

Third, the special relationship doctrine does not expressly provide for a professional standard of care to be applied to the police officers' conduct, nor does it list which factors would determine the appropriate standard. ${ }^{125}$ The pohice duty to rescue, in contrast, lays down a clear rule, stating that police manuals, rules, regulations, and departmental guidelines provide the appropriate standard of care by which to judge police conduct. In sum, although the speeial relationship doctrine remains an important doctrine in tort law for establishing an affirnative duty to act, it does not in its present form sufficiently establish a general duty of the police to rescue those in distress.

Police officers hold a unique position in society: they are protectors of public safety and at the same time they are governmental enployees. This unique role should be acknowledged through a police duty to rescue. Such a duty comports with public expectations of police responsibilities, exposes the police to no undue risk, and requires reasonable affirmative efforts to rescue those in immediate plysical dan-

124. In Williams, Chief Justice Bird cited three factors as evidencing a relationship of dependence: (1) the plaintiff was physically uuable to investigate the accident on her own; (2) the officers had "assumed the responsiblity of investigating the accident"; and (3) it was reasonably foreseeable that the plaintiff would rely on the officers' expertise, and that others would also expect the officers to perform investigative tasks. $34 \mathrm{Cal}$. 3d at 33, $664 \mathrm{P} .2 \mathrm{~d}$ at 146-47, $192 \mathrm{Cal}$. Rptr. at 242.43 (Bird, C.J., dissenting).

125. The doctrine has often been applied in a rather conclusory manner, with no precise guidelines for courts or police officers to follow in an aualysis of police duties. See, e.g., Mann v. State, 70 Cal. App. 3d 773, 139 Cal. Rptr. 82 (1977) (officer wloo assisted strauded inotorist found negligent for failing to warn oncoming traffic before leaving scene), in which the court stated that "clearly plaintiff was dependent upon [defendant] lere" because the defendant, as a state traffic officer who was an expert in traffic safety and charged witl specific responsibility for traffic safety on that stretch of freeway, had acquainted himself witl the plight of the stranded inotorists. $I d$. at 780,139 Cal. Rptr. at 86. This finding of dependence seems to imply that any traffic officcr who assists a citizen creates a special relationship of dependeuce. Unfortunately, not all courts would agree, as evidenced by Williams. As a result, the standard is unclear. 
ger. The recognition of this professional duty and standard of care is both justified and overdue.

Lisa McCabe*

* B.A. 1979, University of California, San Diego; third-year student, Boalt Hall School of Law, University of California, Berkeley. 